\title{
A polymath rediscovered
}

\section{George Rousseau uncovers the physiological side of Hermann von Helmholtz.}

W hen the Harvard University psychologist Edwin Boring dedicated his classic 1942 monograph Sensation and Perception in the History of Experimental Psychology to Hermann von Helmholtz, many American readers wondered why. Helmholtz was a German, the Allies were rallying against the Nazi menace, and the United States had just entered the war. Few beyond professional historians of science knew about Helmholtz's work.

Boring justified his choice: "There is no one else to whom one can owe so completely the capacity to write a book about sensation and perception." Sixty years on, Helmholtz's major contributions to physiology and medicine, including his theories of visual and aural perception, have been largely eclipsed by his work in physics. In Helmholtz, neuroscientist Michel Meulders redresses the balance, showing that this towering figure was as influential as philosopher Immanuel Kant and as visionary as polymath Johann Wolfgang von Goethe.

Part of the reason for Helmholtz's partial invisibility today is that he wrote in German. It took decades for his work to reach the English-speaking world; his Popular Lectures on Scientific Subjects, delivered in the $1850 \mathrm{~s}$, were translated in the 1870 s and 1880 s, and his acoustical masterpiece, On the Sensations of Tone as a Physiological Basis for the Theory of Music (1863), in 1885. After this flurry of works distributed during Helmholtz's last two decades - came tributes on his death in 1894. His Jewish student Leo Koenigsberger published a classic biography, again in German, in 1902, which was translated into English in 1906.

An extensive obituary in the 1896 Proceedings of the Royal Society of London portrayed Helmholtz as the most important physicist of the epoch. His work on the conservation of

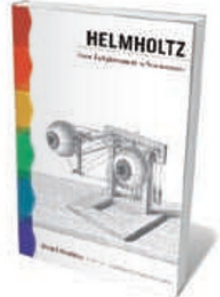

Helmholtz: From Neuroscience MICHEL MEULDERS (TRANSLATED BY LAURENCE GAREY) The MIT Press: 2010. 264 pp. $\$ 27.95$, $£ 20.95$ Enlightenment to

energy that led him to formulate the first law of thermodynamics in 1847 was widely cited - electromagnetism was cutting-edge science. But interest in his physiology and medicine was lost. Helmholtz himself pursued physics more than physiology after the 1870 s, and his theories of sight and sound were bitterly contested well into the twentieth century. Meulders restores Helmholtz's legacy by placing him within the history of science and by locating him as an aesthetic thinker as well as a scientist.

A welcome and surprising inclusion in the book is Helmholtz's role within the aesthetics of music. Meulders is right to retrieve this overlooked aspect - only a handful of specialized monographs have touched on it before. Helmholtz tackled the aesthetics of pitch and tone in 1857, after a century of neglect. "Music has hitherto withdrawn

colour. His view was that music depends on human experience and on the physiology of the senses for its effects. Helmholtz's physiological theory of music had a lasting impact on the composers Alexander Scriabin and Nikolai Rimsky-Korsakov, and on many twentieth-century academic musicologists.

Meulders brings in other German intellectuals on whose work Helmholtz built. For example, he analyses the theory of physics and physiology of colours published by Goethe as Zur Farbenlehre (Colour Theory) in 1810. Yet Goethe does not come to life in the book in the same way as Helmholtz's teacher Johannes Müller, portrayed as a genius who overcame insomnia and depression to hew a science of physiology.

Müller demonstrated in his famous Berlin laboratory that "the results of all physiological research must be, in the end, psychological in nature". Small wonder, then, that he assigned to his protégé Helmholtz a doctoral thesis topic in the 1830s based on invertebrates in Müller's own collection, which was eventually published as Nerve Fibres Arising from the Ganglion Cells Discovered in 1836. In this, Helmholtz built on the ideas of his teacher to bring together physiology and psychology.

Yet curiously, Meulders writes, Helmholtz never referred to the brain. My main reservation is that the book does not unpack this statement. Helmholtz consistently ignored anatomical data on the nervous system, and probably mistrusted the concept, popular at the time, that anatomical and psycho-

itself from scientific treatment, more than any other art," he wrote. Poetry, painting and sculpture borrow from the world of experience, he explained, but music seems to "reject all anatomization of pleasurable sensations".

Helmholtz developed a 'resonator' device, a pierced sphere of glass or brass with a narrow neck, to demonstrate musical pitch and tonal logical processes were identical. Thus he did not link the psychology of perception with the physical brain, and bought into an older theory of mind, with the soul as the arbiter of the senses. Helmholtz's defiance of nineteenth-century natural philosophy through his enduring omission of the brain is strange, and I hope another author will pursue it.

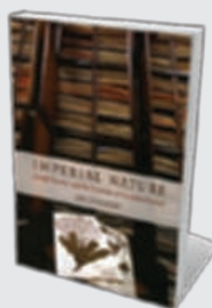

Imperial Nature: Joseph Hooker and the Practices of Victorian Science Jim Endersby (Univ. Chicago Press, 2010; \$25) Botanist Joseph Hooker became one of the first professional scientists when research began to be funded by governments. "A refreshing record of how scientists worked during this transition," wrote Sandra Knapp (Nature 453, 721; 2008).

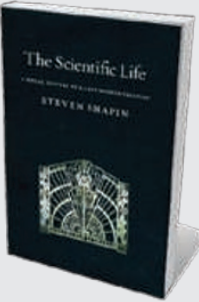

The Scientific Life

Steven Shapin (Univ. Chicago Press, 2010; \$20) Historian Steven Shapin shatters myths about the divide between pure and commercial science by arguing that moral values are as abundant in industry as in academia. Reviewer Jerome Ravetz described it as "required reading for all scientists" (Nature 457, 662-663; 2009). 
Meulders concludes his book with three incisive chapters on the aesthetics of music. In one he deals with the Pythagorean legacy, especially the idea that mathematical relationships were the basis of harmony and tone. In the second he considers 'the musical ear', demonstrating that findings in auricular physiology, particularly Italian anatomist Alfonso Corti's discovery in 1851 of fibres that function as acoustical sensor cells in the cochlea, had complicated the aesthetics of sound.

This chapter is a triumph of compression of a vast province of physiology and aesthetics into a few pages. Surveying the musicological terrain from the argument between Jean-Philippe Rameau and Jean le Rond d'Alembert to Johann Sebastian Bach and Andreas Werckmeister, and on to Mozart and Mendelssohn, Meulders pauses to explain how Helmholtz the empiricist understood

\section{NATURE.COM}

For more on German

science history, see: go.nature.com/R5K70w music theory and aesthetics as a grand unifier. Musical sounds, he thought, can only be understood as great art by combining anatomy, physiology, philosophy and psychology. The third of these chapters meditates on Helmholtz's nostalgia, intuition and memory - an odd amalgam, the breadth of which adds to Meulders's claim for Helmholtz's genius.

Meulders stitches together the thoughts of a lifetime into his slim book. He doesn't surrender his admiration - at times verging on hero worship - despite the occasional critique. The approach is hit-and-miss and does not amount to the much-desired extended interpretation unifying Helmholtz's physiology and aesthetics, but it is a brave start.

Meulders sums up his subject thus: "With his will to unify so many different scientific disciplines in a coherent entity, he proved once again his veritable gluttony for science and knowledge." Some may find Meulders equally gluttonous, but his book demonstrates that Helmholtz was indeed a polymath par excellence.

George Rousseau is a professor of history and co-director of the Centre for the History of Childhood, University of Oxford, Oxford, OX1 4AU, UK. He is author of Nervous Acts. e-mail:george.rousseau@magd.ox.ac.uk

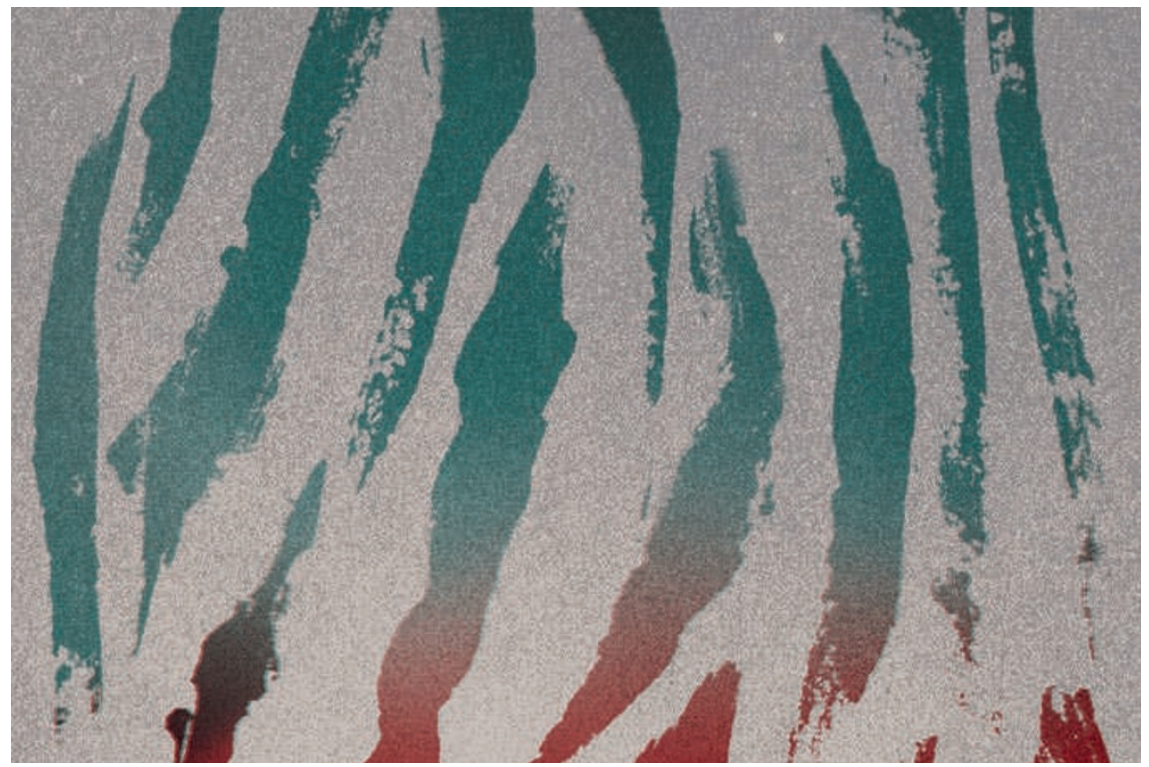

ECOLOGY

\section{Conservation thriller earns its stripes}

\section{A travelogue about tiger poaching in Russia's far east opens up a new genre, discovers Geoff Marsh.}

$\mathrm{Y}$ uri Trush steadily points his camera at the stubs of bone protruding from a pair of thin rubber boots lying in the blood-speckled snow. As the leader of an Inspection Tiger anti-poaching unit, his job now is to piece together the details of Vladimir Markov's run-in with the tiger. Judging by the whimpering of Trush's dog, the big cat in question remains close by, among the trees.

Inspection Tiger is a government agency that was set up to combat poaching in Primorskiy Kray (or Primorye) - an area the size of Washington state in the far east of Russia, bordered by China and North Korea. Trush's team travels in a decommissioned army truck, armed with knives, pistols and semiautomatic rifles. Their mission is to intercept poachers and to resolve

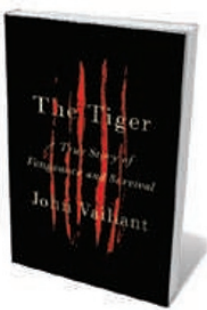

The Tiger: A

True Story of Vengeance and Survival JOHN VAILLANT Sceptre/Alfred Knopf: 2010. 352 pp. $£ 18.99 / \$ 26.95$ of far north. A peculiar mix of hardy alpine

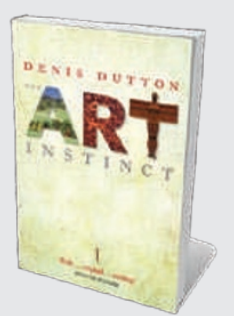

The Art Instinct

Denis Dutton (Oxford Univ. Press, 2010; £9.99)

Art appreciation has an evolutionary basis, according to philosopher Denis Dutton. The basic elements of aesthetic taste are similar across cultures and are part of our evolutionary heritage rather than being socially constructed, he claims provocatively.

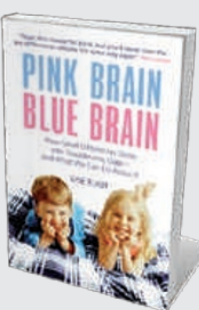

Pink Brain, Blue Brain

Lise Eliot (OneWorld, 2010; £12.99)

Neuroscientist Lise Eliot marshals the latest evidence to show that social pressures are the main cause of behaviour differences between boys and girls. Although small gender variations are apparent at birth, they grow as our plastic brains quickly become modified by experiences. 